\title{
CHRONOLOGY OF THE SWORDS WITH RING POMMEL FROM THE MAEOTIAN SITES ON THE RIGHT BANK OF KUBAN RIVER ${ }^{1}$
}

\author{
Natalya Yu. Limberis \\ Kuban State University, Krasnodar, Russian Federation \\ Ivan I. Marchenko \\ Kuban State University, Krasnodar, Russian Federation
}

\begin{abstract}
The article focuses on the chronological analysis of the Maeotian burials, which contained ring-topped swords. Nowadays, there is a wide range of dating of this type of weapon starting from the $1^{\text {st }}$ century $\mathrm{BC}$ until the $2^{\text {nd }}$ century AD. Recently, as a result of new excavations, the collection of swords of this type extracted from the Maeotian sites on the right bank of the Kuban river has increased significantly, and it has become possible to clarify their chronology in the region. There were found two types of swords and daggers with a ring pommel (62 pieces): I - with a straight barshaped cross-guards; II - no cross-guards. There are also 2 types of blade shape. Swords with a bar-shaped (45 pieces) prevail quantitatively as a result of those excavations. Swords of this type were discovered only in the necropolis of the Spornoye settlement. On the contrary, there was only a single dagger of type II among 11 swords found at the Elizavetinskaya cemetery No. 2. Most of the well-dated assemblages come from the cemeries of the Spornoye, Starokorsunskaya No. 2 and Elizavetinskaya No. 2 settlements. Only two swords are classified as the earliest pieces, which can be referred to the first half of the $1^{\text {st }}$ century $\mathrm{BC}$, according to the accompanying inventory. Another 8 assemblages are dated around the $1^{\text {st }}$ century BC. It is typical of burials containing swords of the $1^{\text {st }}$ century AD to show the presence of fibulae ("Aucissa" type, enamel-less hinged type, etc.), glass cast skyphos and other dating objects, which help to specify the chronology of the assemblages in many cases. Five burials belong to the first half of the $1^{\text {st }}$ century AD, other 11 burials are dated back to the second half of the $1^{\text {st }}$ century $\mathrm{AD}$. The chronology of the rest assemblages is questionable, but only a few burials can be dated to the beginning - the first half of the $2^{\text {nd }}$ century $\mathrm{AD}$. The swords with ring pommel of the Maeotians from the right Kuban bank prevail in the period from the $1^{\text {st }}$ century $\mathrm{BC}$ - the beginning of the $2^{\text {nd }}$ century $\mathrm{AD}$. The latter, most probably indicates that this type of swords with s straight cross-guard was borrowed from the Sarmatians.
\end{abstract}

Key words: Kuban region, Maeotians, dirt cemetery, swords with ring pommel, chronology.

Citation. Limberis N.Yu., Marchenko I.I., 2020. Hronologiya mechey s kol'tsevym navershiem iz meotskih pamyatnikov pravoberezh'ya Kubani [Chronology of the Swords with Ring Pommel from the Maeotian Sites on the Right Bank of Kuban River]. Nizhnevolzhskiy Arkheologicheskiy Vestnik [The Lower Volga Archaeological Bulletin], vol. 19, no. 2, pp. 164-182. DOI: https://doi.org/10.15688/nav.jvolsu.2020.2.9

УДК 930.26(270+571)

ㄱ. ББК 63.48(2)

Дата поступления статьи: 22.07.2020

Дата принятия статьи: 24.11.2020

\section{ХРОНОЛОГИЯ МЕЧЕЙ С КОЛЬЦЕВЫМ НАВЕРШИЕМ ИЗ МЕОТСКИХ ПАМЯТНИКОВ ПРАВОБЕРЕЖЬЯ КУБАНИ ${ }^{1}$}

\author{
Наталья Юрьевна Лимберис \\ Кубанский государственный университет, г. Краснодар, Российская Федерация \\ Иван Иванович Марченко \\ Кубанский государственный университет, г. Краснодар, Российская Федерация
}

Аннотация. Статья посвящена хронологическому анализу меотских погребений, содержавших мечи с кольцевыми навершиями. В настоящее время существует большой разброс в датировках этого типа оружия - 
от І в. до н.э. до II в. н.э. За последнее время в результате новых раскопок коллекция мечей данного типа из меотских памятников правобережья Кубани значительно увеличилась, появилась возможность уточнить их хронологию в этом регионе. Мечи и кинжалы с кольцевым навершием (62 экз.) представлены двумя типами: I - с прямым брусковидным перекрестием; II - без перекрестия. По форме клинка выделено 2 варианта. Количественно преобладают мечи с брусковидным перекрестием (45 экз.). В некрополе городища Спорное встречены только мечи этого типа. Из 11 мечей, найденных на Елизаветинском могильнике № 2, лишь один относится к типу II. Большинство хорошо датированных комплексов происходит из могильников городищ Спорное, Старокорсунское № 2 и Елизаветинское № 2. К самым ранним экземплярам относятся всего два меча, которые по сопровождающему инвентарю можно датировать первой половиной I в. до н.э. Еще 8 комплексов датируются в пределах І в. до н.э. Для погребений с мечами I в. н.э. характерно присутствие фибул (типа «Авцисса», шарнирных без эмали и др.), стеклянных литых скифосов и других датирующих предметов, что дает возможность во многих случаях конкретизировать хронологию комплексов. К первой половине столетия относятся 5 погребений, 11 датируются второй половиной І в. н.э. Хронология остальных комплексов - широкая, однако только несколько погребений могут по датировке «заходить» в начало - первую половину II в. н.э. Основное время бытования мечей с кольцевым навершием у меотов правобережья Кубани следует ограничить I в. до н.э. - началом II в. н.э. Преобладание мечей с прямым перекрестием, вероятно, свидетельствует о заимствовании этого типа меча у сармат.

Ключевые слова: Прикубанье, меоты, грунтовый могильник, мечи с кольцевым навершием, хронология.

Цитирование. Лимберис Н. Ю., Марченко И. И., 2020. Хронология мечей с кольцевым навершием из меотских памятников правобережья Кубани // Нижневолжский археологический вестник. Т. 19, № 2. С. 164-182. DOI: https://doi.org/10.15688/nav.jvolsu.2020.2.9

Проблемы хронологии мечей с кольцевым навершием не раз затрагивались в работах разных исследователей, но разрабатывались они главным образом на материалах из сарматских памятников. В классической работе А.М. Хазанова, посвященной сарматскому вооружению, основной период использования мечей и кинжалов этого типа на Северном Кавказе ограничивется I в. до н.э. I в. н.э., хотя отдельные экземпляры из грунтовых могильников, как он отмечал, могут заходить и во II в. н.э. [Хазанов, 1971, с. 10]. Хронология сарматских мечей с кольцевым навершием успешно разрабатывалась на материалах сарматских памятников Азиатской Сарматии [Скрипкин, 1990, с. 120-125; 2010, c. 336-342; Сергацков, 2007, с. 59, 61].

В данной работе мы не будем затрагивать вопросы датировки мечей с кольцевым навершием из сарматских памятников, а остановимся только на хронологии меотских комплексов правобережья Кубани. Н.В. Анфимов, опираясь на материалы Усть-Лабинского могильника № 2, относил мечи этого типа ко второй половине I в. до н.э. - II в. н.э., отмечая, что в I в. н.э. мечи с кольцевидным навершием постепенно вытесняются мечами без металлического навершия. Нижнюю временную границу он определил, исходя из датировки четвертой хронологической группы погребений [Анфимов, 1951, с. 191, 202]. Хро- нология мечей с кольцевым навершием из сарматских погребений Нижней Кубани была ограничена И.И. Марченко рамками І в. до н.э. II в. н.э. При этом привлекались и материалы меотских грунтовых могильников [Марченко, 1996, с. 54-55]. Количество известных в то время погребений было невелико, а комплексов, датирующихся в пределах одного века или половины столетия, еще меньше. Поэтому мы в свое время датировали мечи с кольцевым навершием из памятников Прикубанья I в. до н.э. - II в. н.э. [Лимберис, Марченко, 1989, с. 81]. С.П. Кожухов, опираясь на меотские и сарматские комплексы Закубанья, находки этого типа вооружения датировал I в. до н.э. серединой II в. н.э. [Кожухов, 1994, с. 7]. М.Ю. Лунев, проанализировав имеющиеся на то время погребения кочевников и оседлого населения Северо-Западного Кавказа, ограничил хронологию мечей с кольцевым навершием второй половиной I в. до н.э. - первой половиной І в. н.э., не исключив возможность их бытования и в третьей четверти указанного столетия [Лунев, 2005, с. 171]. Следует отметить, что в распоряжении всех вышеназванных исследователей не было надежных хронологических реперов для датировки меотских комплексов с мечами этого типа I в. до н.э.

За последнее время в результате новых раскопок коллекция мечей с кольцевым навершием из Прикубанья значительно увеличи- 
лась, и появилась возможность уточнить время их бытования в этом регионе. В данной работе учтено 62 меча с кольцевым навершием из меотских памятников правобережья Кубани: могильников городищ Старокорсунского № 2 (СК-2), хут. Ленина № 1 (Л-1), УстьЛабинского № 2, (УЛ-2), Воронежского № 3, Пашковского № 5, Спорное (СП), Елизаветинского № 2 (ЕЛ-2) ${ }^{2}$ и Тбилисского № 1.

В этих могильниках мечи и кинжалы с кольцевым навершием представлены двумя типами: I - с прямым брусковидным перекрестием (45 экз.); II - без перекрестия (17 экз.). По форме клинка их можно разделить на два варианта: 1 - с параллельными лезвиями, сужающимися в нижней части клинка, ближе к острию; 2 - с удлиненно-треугольным в плане клинком. Клинки мечей второго типа представлены двумя разновидностями: а - основание клинка срезано под прямым углом к рукояти; б - основание срезано под тупым углом. Рассматриваемые экземпляры различаются размерами. А.В. Симоненко предлагает называть кинжалами экземпляры с длиной клинка до $30 \mathrm{~cm}$, а остальные относить к мечам [Симоненко, 2010, с. 32]. В принципе, это условное распределение приемлемо и для меотского клинкового оружия.

Нами выделено 12 экземпляров кинжалов, длина клинков которых колеблется от 20 до 30,5 см. Из них для кинжалов из погребений УЛ-2 № 9/1931 г., 7/1936 г. нам известна лишь общая длина - 28 и 30 см [Анфимов, 1951, с. 197], которая указывает на малые размеры клинков. Остальные экземпляры относятся к мечам, из которых самый большой имеет длину 75 см (размерные характеристики указаны в таблице).

Отметим также, что наблюдаются различия в форме навершия. Большая часть наверший мечей имеет правильную круглую форму кольца, встречаются навершия овальной формы, а один экземпляр из погребения СК-2 № 404з имеет прямоугольно-рамчатое навершие (рис. 3,8$)$. Рукояти у мечей обычно уплощенные, иногда немного расширяющиеся к основанию. Перекрестия узкие, со слабо выступающими концами. Меч из погребения СП № 133 (рис. 1,1) выделяется длинным, слегка изогнутым перекрестием с сильно выступающими, немного расширенными, опу- щенными концами. Рукоять этого меча квадратного сечения. На некоторых экземплярах сохранились следы деревянных ножен и обкладок рукояти.

К сожалению, технологический анализ мечей не проводился. Лишь на мече из погребения СК-2 № 4613 могильника Старокорсунского городища № 2 восстанавливается способ изготовления перекрестия благодаря тому, что на одном конце сварка разошлась. Узкую пластину сгибали пополам, а затем полученную «скобу» заводили сбоку на основание рукояти и клинка, после чего горячей ковкой приваривали к мечу.

О технологии изготовления мечей, которыми пользовалось местное население Северо-Западного Кавказа, дают представление материалы из Цемдолинского некрополя. Три меча с кольцевидным навершием и брусковидным перекрестием из этого памятника были подвергнуты металлографическому изучению. Клинки этих мечей оказались цельностальными. У двух экземпляров это сырцовая сталь, а у одного - высокоуглеродистая цементированная сталь с последующей термической обработкой - твердой закалкой [Розанова, Терехова, 2008, с. 269].

Ранняя группа комплексов (всего - 10) с мечами относится к I в. до н.э. В погребениях этого времени крайне редко встречаются предметы, которые могут сузить хронологические рамки. Главным образом, датировки основываются на местных типах сероглиняных и лепных сосудов.

В погребении СП № 136 вместе с мечом типа I, 2 (рис. 1,2) были найдены псевдокосская амфора [Монахов, 2014, с. 216, 219, рис. 13,64] и литой стеклянный скифос типа ІІа, варианта 1 [Засецкая, Марченко, 1995, с. 96; Лимберис, Марченко, 2003, с. 108]. Эти находки позволили нам ограничить датировку погребения первой половиной I в. до н.э. [Лимберис, Марченко, 2019а, с. 205, рис. 5,6,7,10].

Для датировки погребения Ел-2 № 192/ 2013 г. с мечом типа I, 2 определяющей находкой является сероглиняный канфар на низком кольцевом поддоне, форма которого характерна для последней четверти II - начала І в. до н.э. [Лимберис, Марченко, 2005, с. 238, рис. $23,4,40,5,51,4]$. Здесь же встречен скарабей из египетского фаянса фиолетового цве- 
та с изображением птицы в картуше на обратной стороне (тип 48б), который широко датируется I в. до н.э. - II в. н.э. [Алексеева, 1975 , с. 41 , табл. 10,2]. На этом основании мы можем ограничить датировку погребения началом или первой половиной I в. до н.э.

Погребения СК-2 № 32в и 2463 (рис. $1,8,9$ ) с мечами типа I, 1 могут быть датированы по находке однотипных сероглиняных кувшинов с высоким цилиндрическим горлом и округлым туловом на ложнокольцевом поддоне. Такой же кувшин был найден в погребении СП № 136 [Лимберис, Марченко, 2019 , с. 206-207, pис. 4,8]. Этот тип кувшинов, появившийся в последней четверти II в. до н.э., существовал синхронно с боспорскими красноглиняными образцами, от которых были заимствованы трехлепестковое устье и ложновитые ручки. Эти два признака, как и плоское дно, получили развитие в I в. до н.э. [Лимберис, Марченко, 2005, с. 232, рис. 24,5]. На I в. до н.э. указывает и находка в погребении СК-2 № 32в кухонного горшка с загутым краем, изготовленного на гончарном круге. Такие горшки в I в. н.э. на Старокорсунском городище уже не производились [Лимберис, Марченко, 2005, с. 240]. Наконечник копья из этого же погребения относится к типу III, 4, IV, 2 по нашей классификации, широко распространенному в I в. до н.э. - I в. н.э., а наконечник дротика типа ІІІб с узкой удлиненной головкой и длинными жальцами характерен для II-I вв. до н.э. [Лимберис, Марченко, 2006, c. $173 ; 2012$, с. 412-413]. Наиболее вероятной датой обоих комплексов представляется I в. до н.э., возможно - его первая половина.

При раскопках А.А. Миллера в 1925 г. на могильнике Усть-Лабинского городища № 2 в погребении № 5 был найден меч типа I, 1. В комплекс вооружения входили также наконечники копья и дротика, лепной горшок, сероглиняные миска и кувшин с носиком-сливом и резным орнаментом [Миллер, 1926, с. 8990 , рис. 14,2-4, 18]. Кувшины с носиком сливом характерны для памятников Усть-Лабинской группы. Н.В. Анфимов, публикуя материалы из разрушенного кургана у ст-цы Воронежской, датировал аналогичный кувшин с резным орнаментом I в. н.э. на том основании, что он без кольцевого поддона, а второй кувшин (верхняя часть горла отбита) с рез- ным орнаментом на кольцевом поддоне отнес к I в. до н.э. [Анфимов, 1952, с. 78-81, рис. 20,1,3]. Однако современные материалы показывают, что проводить хронологическую границу по рубежу эр для керамических сосудов только по наличию или отсутствию поддонов вряд ли правомерно. Так, в погребении № 96 могильника городища Спорное вместе с кувшином со сливом, без поддона, была найдена амфора «круга Родоса» второй половины II в. до н.э. [Бочковой и др., 2005, с. 173, рис. $4,3,4]$. Тип железного наконечника копья (II, 5, IV, 2 по нашей классификации) наиболее широко использовался меотами в период II в. до н.э. - I в н.э. [Лимберис, Марченко, 2006 , с. 165 , рис. 1, 2]. Аналогичный наконечник (II, 5, IV, 1 ) был встречен в погребении с амфорой прикубанской серии второй половины II в. до н.э. [Лимберис, Марченко, 2005, с. 228-229, рис. $41,2,3]$. На датировку погребения УЛ-2 № 5/1925 г. І в. до н.э. указывает и тип лепного горшка с загнутым краем [Лимберис, Марченко, 2005, с. 240].

Набор сероглиняных сосудов (кружкакувшинчик, кувшин с ойнохоевидным сливом, миска с вертикальным краем и миска с отогнутым венчиком на поддоне) из погребений Л-1 № 132, 195, 209, 348, 413/1981 г. с мечами типов I, 2; II, 1a; II, 16 и II, 2a (рис. 2,1,5, 3,1,3) позволяет датировать эти комплексы I в. до н.э.

Многочисленную группу составляют погребения I в. н.э. (всего - 26), для которых характерно присутствие фибул и других датирующих предметов, что дает возможность во многих случаях конкретизировать хронологию комплексов.

В четырех погребениях среди инвентаря присутствовали стеклянные литые скифосы, типология и хронология которых была разработана И.П. Засецкой и И.И. Марченко [Засецкая, Марченко, 1995, с. 92-97] и довольно надежно себя зарекомендовала. В погребениях СК-2 № 28в кинжалу типа I, 1 (рис. 1,11) сопутствовал скифос типа ІІІб, 2. Аналогичный скифос встречен вместе с кинжалом типа I, 2 (рис. 2,8 ) в погребении Л-1 № 367. Однотипные скифосы дают возможность синхронизировать эти комплексы и ограничить их хронологию первой половиной I в. н.э., чему не противоречит наличие в погребении Л-1 
№ 367 серебряного канфара и местных сероглиняных сосудов характерных форм [Лимберис, Марченко, 2019б, с. 237-238, рис. 1-3; Marčenko, Limberis, 2008, S. 297, 386, 387, Kat. Nr. 123, 134].

Одинаковые скифосы (тип IIIa, 3), встреченные в погребении ЕЛ-2 № 122/2013 г. с мечом типа I, 2 и в погребении СП № 297/2004 г. с кинжалом этого же типа, также позволяют датировать указанные комплексы первой половиной І в. н.э. [Засецкая, Марченко, 1995, с. 96-97]. Мечу этого же типа I, 2 из погребения ЕЛ-2 № 130/2013 г. сопутствовал сероглиняный биконический кувшин, схожий по основным морфологическим признакам (форме поддона и биконического тулова) с кувшином из ЕЛ-2 № 122/2013 г. Вероятно, оба погребения очень близки по времени, но все-таки для погребения № 130 у нас нет достаточных оснований сужать датировку, поэтому мы относим его к І в. н.э.

Первой половиной I в. н.э. ограничивается хронология погребения СП № 133/2003 г. с мечом типа I, 1 (рис. 1,1), в котором была найдена фибула типа «Авцисса» [Лимберис, Марченко, 2019a, с. 205, 207, pис. 3,6,10].

В погребениях ЕЛ-2 № 182/2013 г. и УЛ-2 № 55/1938 г. вместе с мечами типа I, 1 были найдены римские шарнирные круглые фибулы с крестовидным центром, без эмали [Анфимов, 1951, рис. 18,12]. А.К. Амброз датировал этот тип застежек второй половиной Iначалом II в. н.э. [Амброз, 1966, с. 31, табл. 14,17]. Их западная хронология не выходит за пределы I в. н.э. Э. Этлингер выделила эти фибулы в тип 40, 1 (Radifibeln, einfach) и датировала 20-50 гг. н.э. [Ettlinger, 1973, S. 29, Taf. 12,14]. Аналогичные фибулы из лагеря Камбодунум входят в группу середины I в. н.э. [Schleiermacher, 1993, S. 35, Taf. 22, Kat. Nr. 303-304], а в лагере Август (тип 7. 6) датируются 40-80 гг. н.э. [Riha, 1994, Taf. 78]. Фибулы этого типа присутствуют в погребениях первой половины I в. н.э. некрополей Золотое [Корпусова, 1983, с. 110-111, табл. I,21] и Усть-Альминского городища в Крыму [Высотская, 1994, с. 100, табл. 31, рис. 32]. В.В. Кропотов, опираясь на западные датировки, относит эти фибулы ко второй - третьей четвертям I в. н.э. [Кропотов, 2010, с. 305]. В елизаветинском погребении вместе с рим- ской фибулой была найдена лучковая подвязная фибула серии I варианта 2 второй половины I - начала II в. н.э. [Кропотов, 2010, c. 72-74]. Взаимовстречаемость фибул позволяет датировать это погребение, как и УстьЛабинское, третьей четвертью I в. н.э.

Погребения СП № 262 и 264/2004 г. с мечами типа I, 1 датируются второй третью I в. н.э. на основании находок в них железных «дугоконечных» пряжек провинциально-римских форм по классификации А.А. Труфанова, который разработал их хронологию для памятников Северного Причерноморья [Труфанов, 2004, с. 164-168].

Хронология погребения Л-1 № 126/1981 г. с мечом типа I, 2 (рис. 2,4) определяется фибулой с овально расширенной спинкой и узкой ножкой, так называемой лебяжьинской серии, 2-го варианта, хронология которого ранее определялась I в. н.э. [Амброз, 1966, с. 55-57]. В.В. Кропотов этот вариант фибул датировал второй половиной I - началом II в. н.э. [Кропотов, 2010, с. 261]. В крымских материалах такие застежки имеют более узкую дату: в пределах середины - третьей четверти I в. н.э. [Пуздровский, 2007, с. 86, 176]. А.В. Симоненко обоснованно датирует подобные фибулы второй половиной I в. н.э. [Симоненко, 2004, с. 144]. К этому времени мы склонны отнести и погребение № 126.

Вместе с мечом типа I, 1 в погребении ЕЛ-2 № 36/1978 г. находилась фибула с узкой пластинчатой спинкой и завитком на конце приемника [Анфимов, 1984, с. 90, 93, табл. VII, 10,17]. В.В. Кропотов относит такие застежки к форме 2 причерноморской серии I и датирует второй половиной I - началом II в. н.э., отмечая, что они встречаются и в более поздних комплексах [Кропотов, 2010, c. 185,196 , рис. $55,8,9]$. Хронологию фибул группы IV с завитком на конце приемника из некрополя Кобякова городища В.М. Косяненко в целом ограничивает I в. н.э. [Косяненко, 1987 , с. $58 ; 2008$, с. 101]. Это наблюдение нам кажется правильным для памятников оседлого населения Нижнего Дона и Прикубанья.

Одинаковые фибулы с расширенной, выпуклой пластинчатой спинкой и завитком на конце приемника (серия I, форма 1 по В.В. Кропотову) происходят из погребений ЕЛ-2 № 78/2013 г. и УЛ-2 № 7/1936 г. [Анфимов, 
1951, с. 198, рис. 18,11$]$, в которых были найдены меч и кинжал типа I, 1 (рис. 2,10). Фибулы датируются, как и вся серия I, второй половиной I - началом II в. н.э. [Кропотов, 2010, с. 185 , рис. 55,3]. В комплексеЕЛ-2 № 78/2013 г. присутствует также лучковая подвязная фибула серии I, варианта 2 второй половины Iначала II в. н.э. [Кропотов, 2010, с. 72-74]. Взаимовстречаемость фибул этих типов позволяет определить датировку погребения № 78 в пределах второй половины І в. н.э. Погребение же УЛ-2 № 7/1936 г., как и ЕЛ-2 № 36/1978 г., отдавая предпочтение датировкам фибул с завитком на конце приемника, предлагаемым В.М. Косяненко, мы относим к I в. н.э.

Датировку погребения УЛ-2 № 88/1938 г. с мечом типа I, 1 определяет совместная находка скифоса из дутого стекла [Анфимов, 1951, с. 197, рис. 17,12]. К. Айсингс приводит большую сводку сосудов этой формы, не делая различия по способу изготовления, и датирует их в пределах I в. до н.э. - I в. н.э. [Isings, 1957, p. 55-56]. Среди стеклянных сосудов из Трира усть-лабинский скифос близок типу 29а I в. н.э. [Goethert-Polaschek, 1977, S. 349, Formeltafel A, 29a]. Этого же типа скифос из Керчи датирован Н.З. Куниной I в. н.э. [Кунина, 1997, с. 310, № 282]. Опираясь на хронологию скифоса, погребение № 88 мы отнесли к I в. н.э. [Marčenko, Limberis, 2008, S. 298, Taf. 112,4].

Меч с кольцевым навершием (тип I, 2) и брусковидным перекрестием был найден в северной камере земляного склепа 1944 г. могильника Тбилисского городища № 1. К сожалению, Н.В. Анфимов в своей статье не указал размеры меча, отметил только широкий массивный клинок, но в отчете даны его размеры: длина меча - 61 см, ширина клинка - 6 см [Анфимов, 1945, л. 18-19]. Данный комплекс автор справедливо отнес к I в. н.э., правда без аргументации [Анфимов, 1947, с. 152,154 , рис. 52]. Рисунок меча приведен в статье Н.Е. Берлизова и И.Н. Анфимова, которые опубликовали материалы из рукописного архива Н.В. Анфимова [Берлизов, Анфимов, 2005 , с. 118 , рис. $3,5,2]$. С мечом были найдены две сероглиняные вазы на высоком полом поддоне [Анфимов, 1947, рис. 54]. М.Ю. Лунев датировал вазы этого типа I в. н.э. [Лу- нев, 2005, с. 169], что подтверждается и новыми находками. Так, вазу из погребения № 289 могильника Старокорсунского городища № 3 по лучковой подвязной фибуле варианта 2 серии I можно датировать второй половиной I - началом II в. н.э. Такая же ваза происходит из погребения ЕЛ-2 № 122/2013 г. со стеклянным скифосом первой половины І в. н.э. В погребении СП № 125 І в. н.э. также присутствуют сероглиняная ваза и бронзовый браслет с коническими шишечками на концах [Лимберис, Марченко, 2019а, с. 193, рис. 2,14]. Проведенный нами хронологический анализ комплексов с браслетами этого типа позволил ограничить время их бытования в Прикубанье I - началом II в. н.э. [Лимберис, Марченко, 2020]. Датировка погребения из Тбилисского могильника, скорее всего, не выходит за пределы I в. н.э.

В комплексе СК-2 № 4613 с кинжалом типа I, 1 (рис. 1,7) встречен листовидный наконечник копья (тип II, 1, I, 1 по нашей классификации), аналогичный экземпляру из погребения СК-2 № 4023, которое на основании находки фибулы «Авцисса» было датировано нами первой половиной I в. н.э. [Лимберис, Марченко, 2006, с. 154-155; Marčenko, Limberis, 2008, S. 387, Taf. 151]. Из этих комплексов происходят и близкие по форме сероглиняные кружки. Однако этих данных недостаточно для того, чтобы сузить дату погребения СК-2 № 4613 до половины столетия. Поэтому его следует датировать I в. н.э.

Так же широко I в. н.э. датируются погребения СК-2 № 115в и 1463 с мечами и кинжалами типа II, 1 , б (рис. 3,9 ) по набору характерных для этого времени сероглиняных сосудов. В погребении СК-2 № 75в, кроме местной керамики, был найден наконечник копья типа II, 5, I, 2 [Лимберис, Марченко, 2006 , с. 164 , рис. 1,2$]$.

Анализ разнообразного погребального инвентаря (деталей портупейного набора, оружия, украшений, железных бритв) из комплексов СП № 98, 125, 143 с мечами типа I вариантов 1 и 2 позволил нам датировать эти погребения также в пределах I в. н.э. [Лимберис, Марченко, 2019а, с. 205-207]. Еще два погребения из указанного могильника (СП № 263/2004 г. и № 291/2004 г.) с мечами типа I, 1 и 1I, 2 можно отнести к этому же вре- 
мени по набору керамики, находке железной бритвы и идентичных костяных квадратных ворворок.

Из погребения ЕЛ-2 № 104/2013 г. происходит меч типа II, 2, а. Здесь же встречен набор бус, в состав которого входит экземпляр из многоцветного стекла со сложным орнаментом в виде чередующихся человеческих лиц. Такие бусы относятся к типам 410 411 и датируются I-II вв. н.э. [Алексеева, 1982 , с. 38 , табл. $48,27,28]$. Однако сероглиняные кувшин и миска из этого комплекса по форме тяготеют к I в. н.э., что и определяет датировку комплекса.

Хронология остальных погребений с мечами (всего - 25) определяется в еще более широких рамках.

Погребение УЛ-2 № 71/1938 г. с мечом типа I, 1 относится к четвертой хронологической группе могильника второй половины I в. до н.э. - II в. н.э. Найденный здесь кувшин с ойнохоевидным сливом [Анфимов, 1951, c. 197 , рис. $16,1,18,2]$ позволяет сузить хронологию погребения и датировать его I в. до н.э. І в. н.э.

В погребении СК-2 № 903 вместе с кинжалом типа II, 1 , а (рис. 3,10 ) найдены удила с подвижными колесовидными псалиями, которые надеты на стержни удил, и железный наконечник копья с треугольно-ромбовидным пером. Такие наконечники копий характерны для меотских комплексов, которые мы отнесли к типу III, 4, IV, 2. Наконечники копий данного варианта появляются во второй половине II в. до н.э. и широко используются в I в. до н.э. - I в. н.э. Вероятно, они заходят и во II в. н.э., судя по широким датировкам некоторых комплексов [Лимберис, Марченко, 2006, с. 172-173]. Подвижные колесовидные удила имеют очень широкую хронологию [Марченко, 1996, с. 75, 76; Лимберис, Марченко, 2013, с. 110-111]. Однако формы сероглиняных кувшина и миски на поддоне больше тяготеют к I в. до н.э. - I в. н.э.

Для датировки некоторых погребений единственной привязкой могут быть лишь наборы меотских сероглиняных сосудов и наконечники копий с треугольно-ромбовидным пером, характерные для І в. до н.э. - I в. н.э.: Л-1 № 400 с мечом типа I, 2 (рис. 2,6), СК-2 № 1533, 4043, Л-1 № 252, 387 с мечами и кин- жалом типа II, 1, б (рис. 3,2,7,8,11), Л-1 № 28/1983 г. (в этом парном погребении было два одинаковых меча) и Л-1 № 355 с мечами II, 1, а (рис. 3,4,5,6).

Погребение СП № 151 с кинжалом типа I, 2 ранее было датировано нами І в. до н.э. I в. н.э. [Лимберис, Марченко, 2019a, с. 206,207 , рис. 7$]$.

Погребение СП № 277/2004 г. с мечом типа I, 1 по браслету с коническими шишечками на концах следует датировать I - началом II в. н.э., так как этим периодом мы ограничиваем время их бытования в Прикубанье [Лимберис, Марченко, 2020].

В нескольких погребениях (Л-1 № 14/ 1981 г., СК-2 № 5033, ЕЛ-2 № 22, 61, 80, 84/2013 г.) с мечами типа I, 1 (рис. 1,10,2,2) были встречены лучковые подвязные фибулы варианта 2, которые и определяют хронологические рамки комплексов в пределах второй половины I начала II в. н.э. [Кропотов, 2010, с. 72-73].

Погребение № 73/1966 г. из могильника Воронежского городища № 3, где был найден кинжал типа I, 1, Н.В. Анфимов датировал в отчете I-II вв. н.э. [Анфимов, 1967, л. 42-43, 75 , черт. 75]. Эта датировка подтверждается находкой в погребении маленькой фибулы I начала II в. н.э. с кнопкой на конце приемника, варианта 1 [Кропотов, 2010, с. 213].

Из погребения ЕЛ-2 № 157/2013 г. (с мечом типа I, 2) происходит наконечник копья типа III, 5, I, 2 по нашей классификации, который датируется по фибулам I - первой половиной II в. н.э. [Лимберис, Марченко, 2006, с. 174 , рис. 1,2$]$.

Меч типа II, 1, б из погребения № 197/ 1967 г. могильника Воронежского городища № 3 - самый длинный в нашей коллекции. В отчете Н.В. Анфимова указана его общая длина -75 см. С мечом был найден только железный нож, который не позволяет установить узкую датировку. Автор раскопок датировал погребение I-II вв. н.э. [Анфимов, 1968, л. $48,63,65$, черт. 77$]$.

Невыразительный инвентарь (сероглиняный кувшин, форма которого не восстанавливается, бусина и железная пряжка) сопровождал меч типа I, 1 в погребении № 3/1972 г. Пашковского городища № 5. Н.В. Анфимов в своем отчете отнес это погребение к I-II вв. н.э. [Анфимов, 1973, л. 3-4, черт. 4]. 
В погребении УЛ-2 № 10/1925 г., кроме меча типа I, 1, были найдены удила с колесовидными псалиями, наконечник дротика, сероглиняная миска и лепной горшок с отогнутым венчиком [Миллер, 1926, с. 91-92, рис. $14,3,17]$. Детали конструкции удил, которые являются хронологическими признаками, неизвестны. Удила с колесовидными псалиями, появившиеся у сармат и меотов Прикубанья в I в. до н.э., использовались ими на протяжении длительного периода, если точнее - до середины III в. н.э. [Лимберис, Марченко, 2013, с. 110-111]. Тип наконечника дротика также остается неясным. Этот вид метательного оружия, особенно широко распространенный у меотов во II в. до н.э., редко применялся в I-II вв. н.э. [Лимберис, Марченко, 2012, c. 413]. Горшки с отогнутым венчиком, встречающиеся в погребениях Усть-Лабинского могильника значительно реже горшков с загнутым краем [Анфимов, 1951, с. 192, рис. 15,4], скорее всего датируются I-II вв. н.э., как и в меотских памятниках Краснодарской группы. Для населения же городища Спорное этот тип кухонных горшков остается весьма популярным с IV в. до н.э. до первых веков н.э. В упоминавшемся уже погребении СП № 136 первой половины I в. до н.э. среди инвентаря присутствуют горшок с отогнутым краем и удила с колесовидными псалиями [Бочковой и др., 2005 , рис. $2,2,4,2,5,3,8,4,10,6,17,4]$. Также и в погребении СП № 151, которое мы датировали I в. до н.э. - I в. н.э., имеется горшок с отогнутым краем [Лимберис, Марченко, 2019, рис. 7,5]. Все сказанное дает нам основания только для широкой датировки погребения № 10 в пределах I в. до н.э. - II в. н.э.

Так же широко датируются погребения из УЛ-2 № 9/1931 г. (кинжал типа I, 1) и 22/ 1932 г. (меч типа I, вариант неизвестен), которые Н.В. Анфимов отнес к четвертой хронологической группе - второй половины І в. до н.э. - II в. н.э. [Анфимов, 1951, с. 197].

К I в. до н.э. - II в. н.э. нужно отнести и погребение Л-1 № 11/1980 г., так как здесь не было другого инвентаря, кроме меча типа I, 1 (рис. 2,7).

Хронологический анализ погребений позволяет сделать некоторые выводы. К самым ранним экземплярам из погребений СП № 136 и ЕЛ-2 № 192/2013 г. относятся всего два меча типа I, 2, которые по сопровождающему инвентарю можно датировать первой половиной I в. до н.э. Еще 8 комплексов с мечами разных типов датируются в пределах I в. до н.э.

Датировка 26 комплексов с мечами ограничивается пределами I в. н.э. Из них к первой половине столетия относятся 5 погребений с мечами типов I, 1 и I, 2. Узкую дату в пределах второй половины I в. н.э. имеют 4 погребения с мечами типа I, 1.

Хронология остальных 25 комплексов с мечами и кинжалами разных типов - очень широкая - I в. до н.э. - II в. н.э., причем датировка 10 погребений не выходит за рамки І в. до н.э. - I в. н.э., и только 9 погребений могут по датировке «заходить» в начало первую половину II в. н.э.

Количественно преобладают мечи с брусковидным перекрестием (45 экз.), что, вероятно, может свидетельствовать о заимствовании этого типа меча у сармат. Но все же меоты сохранили свою традицию изготовления мечей без металлического перекрестия. В некрополе городища Спорное встречены только мечи типа I (с перекрестием). Из 11 мечей, найденных на Елизаветинском могильнике № 2, лишь один относится к типу II (без перекрестия). Большинство хорошо датированных комплексов с мечами происходит из могильников городищ Спорное, Старокорсунское № 2 и Елизаветинское № 2. Основное время бытования мечей с кольцевым навершием у меотов правобережья Кубани можно ограничить I в. до н.э. - началом II в. н.э.

\section{ПРИМЕЧАНИЯ}

${ }^{1}$ Работа выполнена в рамках проекта РФФИ, грант № 18-09-00619 «Военное дело меотов правобережья Кубани (VI в. до н.э. - III в. н.э.)».

The work was funded by RFBR, grant no. 18-09-00619 "Military Affairs of the Maeotians of the Kuban Right Bank ( $6^{\text {th }}$ century BC $3^{\text {rd }}$ century AD)".

${ }^{2}$ Выражаем благодарность Б.А. Раеву за возможность ознакомиться с материалами раскопок могильника городища Спорное (2004 г.) и М.Ю. Луневу, предоставившему материалы раскопок могильника Елизаветинского городища № 2 (2013 г.). 
N.Yu. Limberis, I.I. Marchenko. Chronology of the Swords with Ring Pommel from the Maeotian Sites

\section{ИЛЛЮСТРАЦИИ}

\section{Мечи с кольцевым навершием (размерные характеристики)}

\section{Ring-topped swords (size characteristics)}

\begin{tabular}{|c|c|c|c|c|c|c|c|c|}
\hline $\begin{array}{l}\text { № } \\
\Pi / \Pi\end{array}$ & № погр. & $\begin{array}{c}\text { Длина } \\
\text { меча } \\
\text { (см) } \\
\end{array}$ & $\begin{array}{c}\text { Длина } \\
\text { клинка } \\
(\text { см) } \\
\end{array}$ & $\begin{array}{c}\text { Ширина } \\
\text { клинка } \\
\text { (см) }\end{array}$ & $\begin{array}{c}\text { Длина } \\
\text { рукояти } \\
\text { (см) }\end{array}$ & $\begin{array}{c}\text { Диаметр } \\
\text { навершия } \\
\text { (см) }\end{array}$ & Тип & Дата погребения \\
\hline \multicolumn{9}{|c|}{ Могильник городища № 1 хут. Ленина } \\
\hline 1 & $11 / 1980$ г. & 45,4 & 36 & 2,6 & 6,4 & 3 & $\mathrm{I}, 1$ & І в. До Н.э. - II в. н.э. \\
\hline 2 & 14/1981г. & $\begin{aligned} & 45^{*} \\
& \approx 50,6\end{aligned}$ & $\begin{aligned} & 31 * \\
& \approx 36,6 \\
&\end{aligned}$ & 4 & 9,2 & 4,8 & $\mathrm{I}, 1$ & $\begin{array}{c}\text { 2-я пол. I в. н.э. - } \\
\text { начало II в. н.э. }\end{array}$ \\
\hline 3 & 126/1981 г. & $\begin{aligned} & 48^{*} \\
& \approx 51,9 \\
&\end{aligned}$ & $\begin{aligned} & 36^{*} \\
& \approx 39,9 \\
&\end{aligned}$ & 3,8 & 8 & 4 & $\mathrm{I}, 1$ & 2-я пол. І в. н.э. \\
\hline 4 & 132/1981 г. & $\approx 54,5$ & 40 & 6 & 8,5 & 6 & $\mathrm{I}, 2$ & І в. до н.э. \\
\hline 5 & 195/1981 г. & $\begin{aligned} & 42 * \\
& \approx 59,1 \\
&\end{aligned}$ & $\begin{array}{l}39,4 * \\
\approx 47,3\end{array}$ & 4 & $\begin{array}{l}2,5 * \\
\approx 7,8 \\
\end{array}$ & $\approx 4$ & $\mathrm{II}, 1, \mathrm{a}$ & І в. до н.э. \\
\hline 6 & 209/1981 г. & $\approx 65,1$ & 53 & 4 & 7,7 & 4,4 & II, 1,6 & І в. до н.э. \\
\hline 7 & 252/1981 г. & 59 & 46 & 3,5 & 9 & 4 & $\mathrm{II}, 1,6$ & І в. До Н.э. - І в. Н.э. \\
\hline 8 & 348/1981 г. & 57 & 45 & 4 & 9 & 3 & $\mathrm{II}, 2, \mathrm{a}$ & I в. до н.э. \\
\hline 9 & 355/1981 г. & 55 & 42,7 & 4,5 & 8,9 & 3,4 & II, $1, \mathrm{a}$ & І в. ДО Н.Э. - І в. Н.Э. \\
\hline 10 & 367/1981 г. & 41 & 30 & 4,5 & 6,5 & 4,5 & $\mathrm{I}, 2$ & 1-я пол. І в. н.э. \\
\hline 11 & 387/1981 г. & 49 & 36 & 5 & 7 & 6 & II, 1,6 & І в. до н.э. - I в. н.э. \\
\hline 12 & 400/1981 г. & $\begin{aligned} & 43 * \\
\approx & 46,1\end{aligned}$ & 34 & 3,8 & 8 & $\approx 4,1$ & $\mathrm{I}, 2$ & І в. до н.э. - I в. н.э. \\
\hline 13 & 413/1981 г. & $\begin{array}{l}46,5 * \\
\approx 59,2 \\
\end{array}$ & $\begin{aligned} & 42 * \\
& \approx 43,3 \\
&\end{aligned}$ & 4,6 & 9,5 & 6,4 & $\mathrm{I}, 2$ & І в. до н.э. \\
\hline 14 & \multirow{2}{*}{ 28/1983 г. } & $\begin{array}{c}50 * \\
\approx 53,5 \\
\end{array}$ & 43 & 4,5 & 5,9 & 4,6 & II, $1, \mathrm{a}$ & \multirow{2}{*}{ І в. до н.э. - I в. н.э. } \\
\hline 15 & & $\begin{aligned} & 50 * \\
& \approx 57 \\
&\end{aligned}$ & $\begin{array}{c}42 * \\
\approx 43,7\end{array}$ & 4 & 7 & $\approx 6,3 \times 8,6$ & II, $1, ?$ & \\
\hline \multicolumn{9}{|c|}{ Могильник городища Спорное } \\
\hline 16 & $98 / 2003$ г. & 44,1 & 32,3 & 4,7 & 7,3 & $4,9 \times 4,5$ & $\mathrm{I}, 2$ & І в. н.э. \\
\hline 17 & $125 / 2003$ г. & 49,6 & 37,8 & 3,7 & 8,3 & 3,5 & $\mathrm{I}, 1$ & І в. н.э. \\
\hline 18 & $133 / 2003$ г. & 60 & 47,2 & 3,4 & 7,8 & $5 \times 4,4$ & $\mathrm{I}, 1$ & 1-я пол. І в. н.э. \\
\hline 19 & $136 / 2003$ г. & 53 & 39 & 6,2 & 9,4 & $6,8 \times 4,6$ & $\mathrm{I}, 2$ & 1-я пол. І в. до н.э. \\
\hline 20 & $143 / 2003$ г. & $\begin{array}{l}46,7 * \\
\approx 48,2\end{array}$ & $\begin{array}{l}35,6^{*} \\
\approx 37,2\end{array}$ & 5,5 & 7,2 & 3,8 & $\mathrm{I}, 2$ & І в. н.э. \\
\hline 21 & $151 / 2003$ г. & 38,8 & 26,6 & 5,1 & 7,3 & 4,9 & $\mathrm{I}, 2$ & І в. До н.э. - І в. Н.Э. \\
\hline 22 & 262/2004 г. & $\approx 60$ & $\approx 47$ & 4 & 9 & 4 & $\mathrm{I}, 1$ & 2-я треть I в. н.э. \\
\hline 23 & 263/2004 г. & 59,7 & 48,7 & 4 & 7,5 & $5,2 \times 3,5$ & $\mathrm{I}, 1$ & І в. н.э. \\
\hline 24 & $264 / 2004$ г. & $40 *$ & $31,3 *$ & 3,8 & $8,7 *$ & - & $\mathrm{I}, 1$ & 2-я треть I в. н.э. \\
\hline 25 & $277 / 2004$ г. & 44 & 33 & 3,5 & 7 & 4 & $\mathrm{I}, 1$ & I - нач. II в. н.э. \\
\hline 26 & 291/2004 г. & 48 & 37 & 5,1 & 8,4 & 2,6 & $\mathrm{I}, 2$ & І в. н.э. \\
\hline 27 & 297/2004 г. & $38,2 *$ & 27,8 & 5,9 & $9,2 *$ & - & $\mathrm{I}, 2$ & 1-я пол. І в. н.э. \\
\hline \multicolumn{9}{|c|}{ Могильник Старокорсунского городища № 2} \\
\hline 28 & $28 \mathrm{~B}$ & 37,8 & 28,2 & 4,9 & \begin{tabular}{l|l}
6,6 & \\
\end{tabular} & 3 & $\mathrm{I}, 2$ & 1-я пол. І в. н.э. \\
\hline 29 & $32 \mathrm{~B}$ & $\approx 54,4$ & $\begin{aligned} & 40 * \\
\approx & 41,5\end{aligned}$ & 4,2 & 8,5 & $4,4 \times 5,8$ & $\mathrm{I}, 1$ & І в. до н.э. \\
\hline 30 & $75 \mathrm{~B}$ & 32,8 & 21,5 & 3,5 & 7,5 & 3,8 & II, 1,б & І в. н.э. \\
\hline 31 & 903 & $\begin{aligned} & 38 * \\
\approx & 42,4\end{aligned}$ & 30 & 4,3 & 8 & $\approx 4,2$ & II, $1, \mathrm{a}$ & І в. до н.э. - І в. н.э. \\
\hline 32 & $115 \mathrm{~B}$ & 45,8 & 34 & 3,4 & 8,3 & $3,7 \times 3,5$ & II, 1,6 & І в. н.э. \\
\hline 33 & 1463 & $38 *$ & 26,7 & 4,6 & 9,5 & Ок. 3,5 & II, 1,6 & І в. н.э. \\
\hline 34 & 1533 & 42,1 & 30,5 & 3,5 & 8,3 & $3,3 \times 4,5$ & II, 1,6 & І в. До Н.э. - I в. н.э. \\
\hline 35 & 2463 & 48,6 & 36,5 & 3,8 & 8,1 & 4 & $\mathrm{I}, 1$ & I в. до н.э. \\
\hline 36 & 4043 & 46,2 & 34,2 & 3,2 & 8 & $4 \times 2,8$ & II, 1,6 & І в. До Н.э. - I в. н.э. \\
\hline 37 & 4613 & 57,2 & 45 & 4,4 & 8 & 4,2 & $\mathrm{I}, 1$ & I в. н.э. \\
\hline 38 & 5033 & 39,3 & 26,2 & 2,6 & 10,8 & 2,3 & $\mathrm{I}, 1$ & $\begin{array}{c}\text { 2-я пол. I - начало II в. } \\
\text { н.э. }\end{array}$ \\
\hline
\end{tabular}




\section{Окончание таблицы}

End of Table

\begin{tabular}{|c|c|c|c|c|c|c|c|c|}
\hline $\begin{array}{l}\text { № } \\
\Pi / \Pi\end{array}$ & № погр. & $\begin{array}{l}\text { Длина } \\
\text { меча } \\
(\text { см) } \\
\end{array}$ & $\begin{array}{c}\text { Длина } \\
\text { клинка } \\
\text { (см) } \\
\end{array}$ & $\begin{array}{c}\text { Ширина } \\
\text { клинка } \\
\text { (см) }\end{array}$ & $\begin{array}{c}\text { Длина } \\
\text { рукояти } \\
\text { (см) } \\
\end{array}$ & $\begin{array}{c}\text { Диаметр } \\
\text { навершия } \\
\text { (см) } \\
\end{array}$ & Тип & Дата погребения \\
\hline \multicolumn{9}{|c|}{ Могильник Елизаветинского городища № 2} \\
\hline 39 & 36/1978 г. & $\begin{array}{l}49 * \\
\approx 56\end{array}$ & $\begin{array}{l}35,3 * \\
\approx 42,5\end{array}$ & 3,4 & 9,2 & 4,3 & $\mathrm{I}, 1$ & 2-я пол. І в. н.э. \\
\hline 40 & $22 / 2013$ г. & 52,4 & 39,2 & 3,4 & 9,2 & 4 & $\mathrm{I}, 1$ & 2-я пол. I - начало II в. н.э. \\
\hline 41 & $61 / 2013$ г. & 40 & 29 & 2,8 & 11 & & $\mathrm{I}, 1$ & $\begin{array}{c}\text { 2-я пол. I - начало II в. } \\
\text { н.э. }\end{array}$ \\
\hline 42 & 78/2013 г. & $33,4 *$ & $18,9 *$ & 2,8 & 12,1 & 2,4 & $\mathrm{I}, 1$ & 2-я пол. І в. н.э. \\
\hline 43 & $80 / 2013$ г. & $\begin{array}{l}55,4^{*} \\
\approx 58\end{array}$ & $\begin{array}{l}43,4 * \\
\approx 46\end{array}$ & 4,2 & 8 & 4 & $\mathrm{I}, 1$ & $\begin{array}{c}\text { 2-я пол. I - начало II в. } \\
\text { н.э. }\end{array}$ \\
\hline 44 & 84/2013 г. & 55,4 & 44,6 & 5 & 6,6 & 4,2 & $\mathrm{I}, 1$ & 2-я пол. I - начало II в. н.э. \\
\hline 45 & 104/2013 г. & 55,2 & 41,7 & 6 & 7,7 & 5,8 & II, $2, \mathrm{a}$ & І в. н.э. \\
\hline 46 & $122 / 2013$ г. & $50 *$ & $37,5 *$ & 4,6 & 7,5 & 5 & $\mathrm{I}, 2$ & 1-я поЛ. І в. н.э. \\
\hline 47 & 130/2013 г. & 55,4 & 42,6 & 5,2 & 8,2 & 4,6 & $\mathrm{I}, 2$ & І в. н.э. \\
\hline 48 & $157 / 2013$ г. & $33 *$ & $24 *$ & 3,4 & 8 & 3 & $\mathrm{I}, 2$ & I - 1-я пол. II в. н.э. \\
\hline 49 & $182 / 2013$ г. & 43 & 32 & 3,2 & 11 & & $\mathrm{I}, 1$ & 3-я четверть I в. н.э. \\
\hline 50 & 192/2013 г. & $51,5 *$ & $40,3 *$ & 6,5 & 7,8 & 3,4 & $\mathrm{I}, 1$ & 1-я пол. І в. до н.э. \\
\hline \multicolumn{9}{|c|}{ Могильник Тбилисского городища № 1} \\
\hline 51 & $\begin{array}{c}\text { Земляной } \\
\text { склеп/1944 г. }\end{array}$ & 61 & - & 6 & - & - & $\mathrm{I}, 2$ & І в. н.э. \\
\hline \multicolumn{9}{|c|}{ Могильник Усть-Лабинского городища № 2} \\
\hline 52 & $5 / 1925$ г. & 51,5 & - & - & - & - & $\mathrm{I}, 1$ & І в. до н.э. \\
\hline 53 & $10 / 1925$ г. & 58 & - & - & - & - & $\mathrm{I}, 1$ & І в. До н.э. - II в. н.э. \\
\hline 54 & 9/1931 г. & 28 & - & 3 & - & - & $\mathrm{I}, 1$ & $\begin{array}{c}\text { 2-я пол. І в. до н.э. - II в. } \\
\text { н.э. }\end{array}$ \\
\hline 55 & 22/1932 г. & 40 & - & 4 & - & - & $\mathrm{I}, ?$ & $\begin{array}{c}\text { 2-я пол. І в. до н.э. - II в. } \\
\text { н.э. }\end{array}$ \\
\hline 56 & $7 / 1936$ г. & 30 & - & 3 & - & - & $\mathrm{I}, 1$ & І в. н.э. \\
\hline 57 & 55/1938 г. & 47 & 35 & 4 & 8 & 4 & II, 1,6 & 3-я четверть I в. н.э. \\
\hline 58 & 71/1938 г. & 49 & 38 & 4 & 7 & 4 & $\mathrm{I}, 1$ & І в. До Н.э. - І в. Н.э. \\
\hline 59 & $88 / 1938$ г. & 57 & 45 & 4 & 8 & 4 & $\mathrm{I}, 2$ & І в. н.э. \\
\hline \multicolumn{9}{|c|}{ Могильник Воронежского городища № 3} \\
\hline 60 & 73/1966 г. & $\approx 30$ & - & - & - & - & $\mathrm{I}, 1$ & I - начало II в. н.э. \\
\hline 61 & 197/1967 г. & 75 & - & - & - & - & II, 1,6 & I-II вв. н.э. \\
\hline \multicolumn{9}{|c|}{ Могильник Пашковского городища № 5} \\
\hline 62 & 3/1972 г. & 50 & - & - & - & - & $\mathrm{I}, 1$ & I-II вв. Н.э. \\
\hline
\end{tabular}

Примечание. * - сохранившаяся длина; $\approx$ - реконструированная длина. 


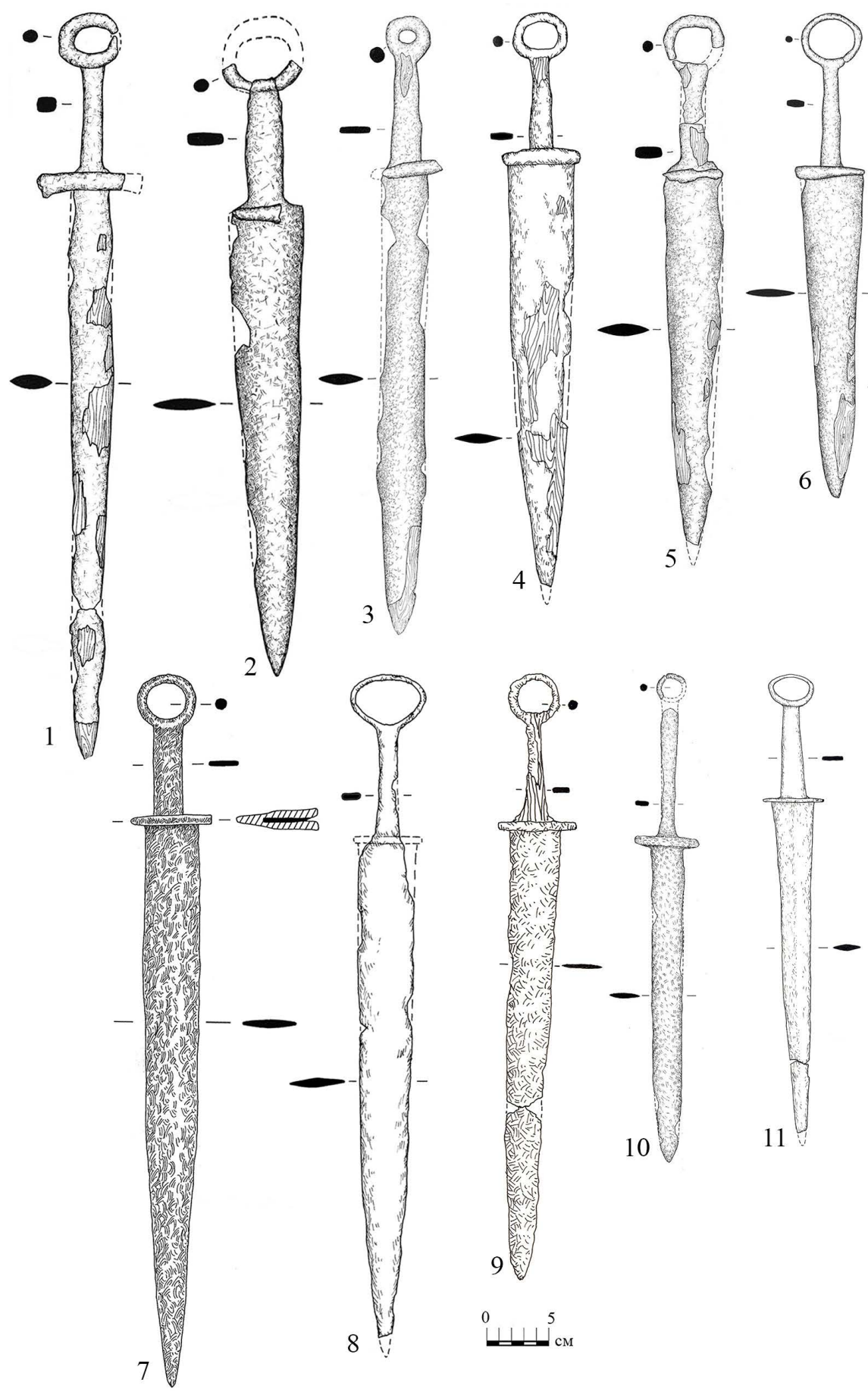

Рис. 1. Мечи с кольцевым навершием:

1-6 - могильник городища Спорное (1 - погр. 133, 2 - погр. 136, 3 - погр. 125, 4 - погр. 143, 5 - погр. 98, 6 - погр. 151);

7-11 - могильник Старокорсунского городища № 2 (7 - погр. 4613, 8 - погр. 32в, 9 - погр. 2463, 10 - погр. 503з, 11 - погр. 28в)

Fig. 1. Swords with a ring top:

1-6 - cemetery of the Spornoye settlement ( 1 - burial No. 133, 2 - burial No. 136, 3 - burial No. 125,

4 - burial No. 143,5 - burial No. 98,6 - burial No. 151);

7-11 - cemetery Starokorsunskaya settlement No. 2 ( 7 - burial No. 4613, 8 - burial No. 32B, 9 - burial No. 2463, 10 - burial No. 5033, 11 - burial No. 28в) 

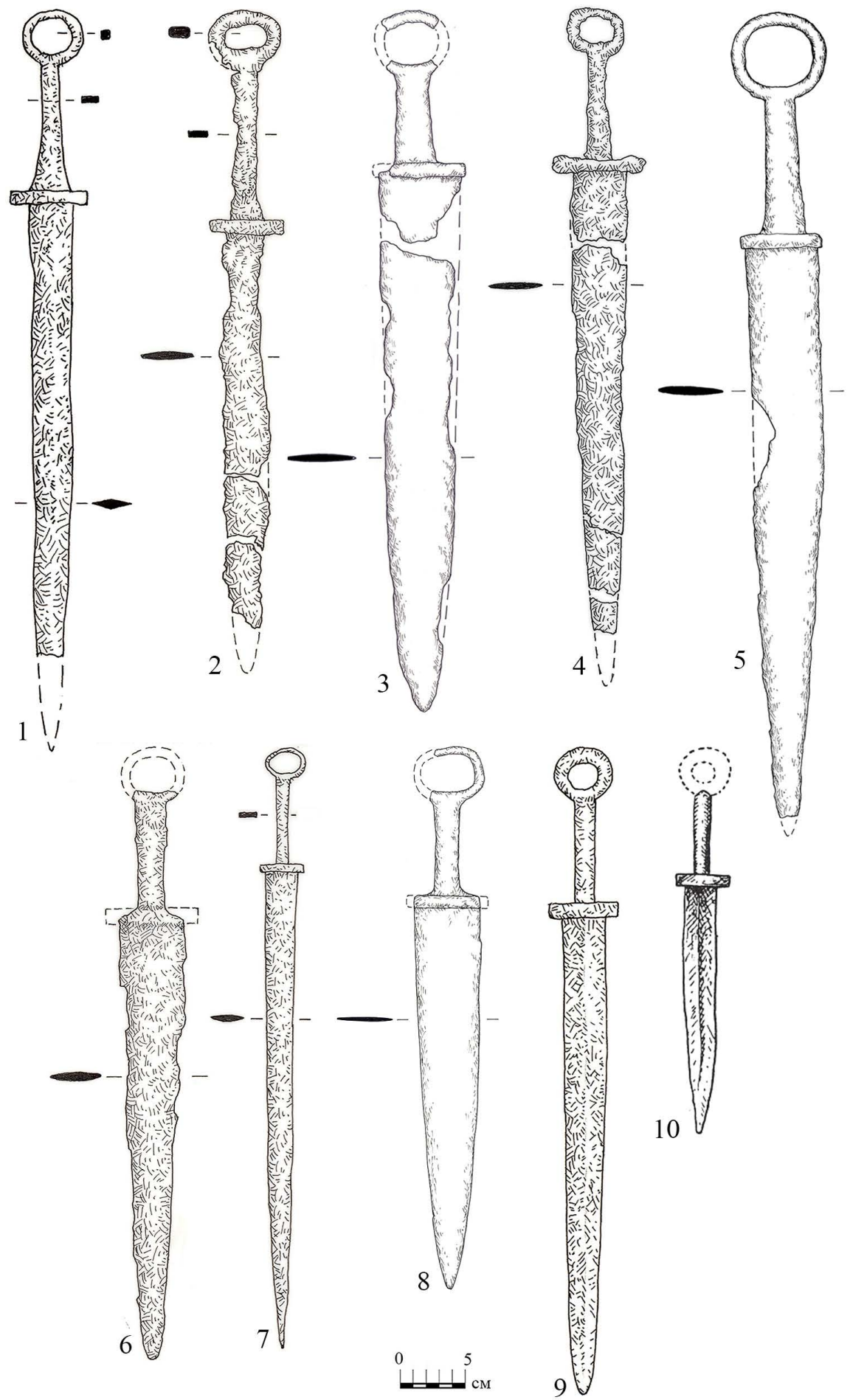

Рис. 2. Мечи с кольцевым навершием:

1 - погр. 36/1978 г. Елизаветинского могильника № 2; 2-8 - могильник городища № 1 хут. Ленина (2 - погр. 14, 3 - погр. 132, 4 - погр. 126, 5 - погр. 413, 6 - погр. 400, 7 - погр. 11/1980 г., 8 - погр. 367);

9-10 - могильник Усть-Лабинского городища № 2 (9 - погр. 71/1938 г., 10 - погр. 7/1936 г.)

Fig. 2. Swords with a ring top:

1 - Burial No. 36/1978 of the Elizavetinskaya cemetery No. 2; 2-8 - cemetery of the settlement No. 1 of Lenin's farm (2 - burial No. 14, 3 - burial No. 132, 4 - burial No. 126, 5 - burial No. 413, 6 - burial no. 400, 7 - burial No. 11/1980, 8 - burial No. 367);

9-10 - cemetery of the Ust-Labinsk settlement No. 2 ( 9 - burial No. 71/1938, 10 - burial No. 7/1936) 


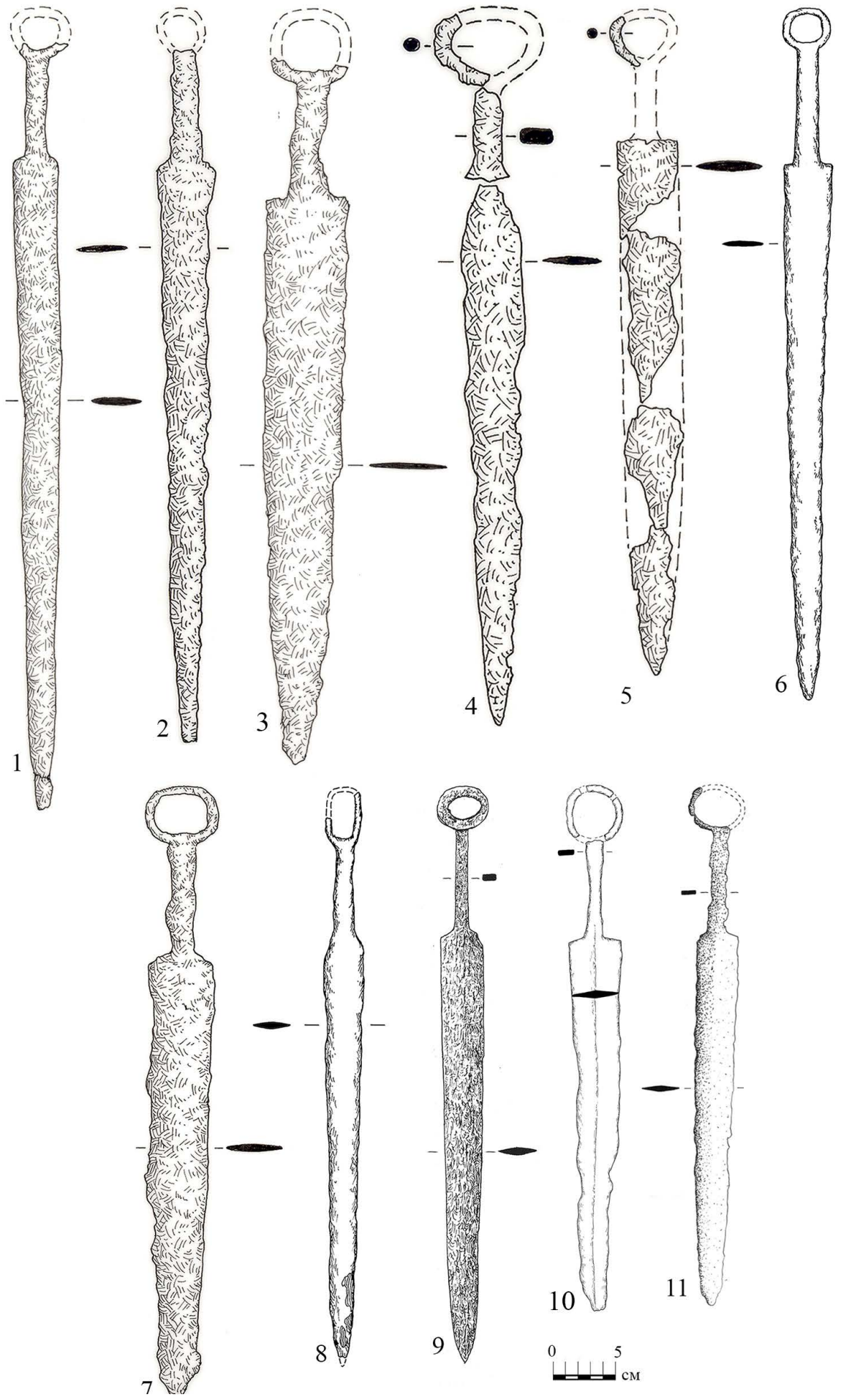

Рис. 3. Мечи с кольцевым навершием:

1-7 - могильник городища № 1 хут. Ленина ( 1 - погр. 209, 2 - погр. 252,

3 - погр. 348, 4, 5 - погр. 28/1983 г., 6 - погр. 355, 7 - погр. 387);

8-11 - могильник Старокорсунского городища № 2 (8 - погр. 4043, 9 - погр. 115в,

$$
10 \text { - погр. } 903,11-\text { погр. 1533) }
$$

Fig. 3. Swords with ring top:

1-7 - cemetery of the settlement No. 1 of Lenin's farm ( 1 - burial No. 209, 2 - burial No. 252 ,

3 - burial No. 348, 4, 5 - burial No. 28/1983, 6 - burial No. 355, 7 - burial No. 387);

$8-11$ - cemetery of the Starokorsunskaya settlement No. 2 ( 8 - burial No. 4043,9 - burial No. 115 в,

10 - burial No. 903,11 - burial No. 1533) 


\section{СПИСОК ЛИТЕРАТУРЫ}

Алексеева Е. М., 1975. Античные бусы Северного Причерноморья. САИ. Вып. ГІ-12. М. : Наука. 94 с.

Алексеева Е. М., 1982. Античные бусы Северного Причерноморья. САИ. Вып. ГІ-12. М. : Наука. 104 с.

Амброз А. К., 1966. Фибулы юга европейской части СССР II в. до н. э. - IV в. н. э. САИ Д1-30. М. : Наука. 111 с., 28 табл.

Анфимов И. Н., 1984. Меотский могильник I-IІ вв. н.э. близ станицы Елизаветинской // Вопросы археологии Адыгеи. Майкоп : Адыгейский НИИ ЭЯЛИ. С. 83-114.

Анфимов Н. В., 1945. Отчет об археологических исследованиях, проведенных в Тбилисском и Ладожском районах Краснодарского края в 1944 г. // Архив ИА РАН. Ф-1. Р-1. № 5.39 л., 17 ил.

Анфимов Н. В., 1947. Земляные склепы сарматского времени в грунтовых могильниках Прикубанья // Краткие сообщения института истории и материальной культуры. Вып. 16. С. 148-157.

Анфимов Н. В., 1951. Меото-сарматский могильник у станицы Усть-Лабинской // Материалы и исследования по археологии Северного Кавказа. Материалы и исследования по археологии СССР. № 23. М.; Л. : Изд-во Академии наук СССР. С. 155-207.

Анфимов Н. В., 1952. Новые материалы по меото-сарматской культуре Прикубанья // Краткие сообщения института истории и материальной культуры. Вып. 46. С. 72-85.

Анфимов Н. В., 1967. Отчет об археологических исследованиях, проведенных в Краснодарском крае в 1966 г. // Архив ИА РАН. Р-1, № 3806.

Анфимов Н. В., 1968. Отчет об археологических работах, связанных с охранными мероприятиями, проведенных в 1967 г. // Архив ИА РАН. Р-1, № 3807.

Анфимов Н. В., 1973. Отчет о раскопках Пашковского 5-го могильника в 1972 г. // Архив ИА РАН. Р-1. № 6505.

Берлизов Н. Е., Анфимов И. Н., 2005. Могильники Среднего Прикубанья эпохи позднего эллинизма и римского времени (по материалам рукописного архива Н.В. Анфимова) // Материалы и исследования по археологии Северного Кавказа. Вып. 5. Армавир : АГПУ. С. 113-125.

Бочковой В. В., Лимберис Н. Ю., Марченко И. И., 2005. Погребения с амфорами из могильника городища Спорное // Материалы и исследования по археологии Кубани. Вып. 5. Краснодар : КубГУ. С. 172-218.

Высотская Т. Н., 1994. Усть-Альминское городище и некрополь. Материалы по археологии Крыма. Киев : Академия Евробизнеса. 208 с.

Засецкая И. П., Марченко И.И., 1995. Классификация стеклянных канфаров позднеэллинистического и раннеримского времени // Археологический сборник Государственного Эрмитажа. Вып. 32. С. 90-104.

Кожухов С. П., 1994. Вооружение и конское снаряжение у племен Закубанья в меото-сарматское время (III в. до н.э. - III в. н.э.) : автореф. дис. ... канд. ист. наук. М. : ИА РАН. 22 с.

Корпусова В. Н., 1983. Некрополь Золотое (К этнокультурной истории европейского Боспора). Киев : Наукова Думка. 184 с.

Косяненко В. М., 1987. Бронзовые фибулы из некрополя Кобякова городища // Советская археология. № 2. C. $45-62$.

Косяненко В. М., 2008. Некрополь Кобякова городища (по материалам раскопок 1956-1962 гг.). Донские древности. Вып. 9. Азов : Азовский историко-археологический и палеонтологический музей-заповедник. 544 c.

Кропотов В. В., 2010. Фибулы сарматской эпохи. Киев : ИА НАНУ; АДЕФ-Украина. 384 с.

Кунина Н., 1997. Античное стекло в собрании Эрмитажа. СПб. : Государственный Эрмитаж ; АРС. 358 с.

Лимберис Н. Ю., Марченко И. И., 1989. Хронология мечей из сарматских памятников Прикубанья // Первая кубанская археологическая конференция. Краснодар : КубГУ. С. 80-82.

Лимберис Н. Ю., Марченко И. И., 2003. Стеклянные сосуды позднеэллинистического и римского времени из Прикубанья // Материалы и исследования по археологии Кубани. Вып. 3. Краснодар : КубГУ. С. 106-183.

Лимберис Н. Ю., Марченко И. И., 2005. Хронология керамических комплексов с античными импортами из раскопок меотских могильников правобережья Кубани // Материалы и исследования по археологии Кубани. Вып. 5. Краснодар : КубГУ. С. 219-324. 
N.Yu. Limberis, I.I. Marchenko. Chronology of the Swords with Ring Pommel from the Maeotian Sites

Лимберис Н. Ю., Марченко И. И., 2006. Типология и хронология железных наконечников копий из памятников правобережья Кубани // Материалы и исследования по археологии Кубани. Вып. 6. Краснодар : КубГУ. С. 152-181.

Лимберис Н. Ю., Марченко И. И., 2012. Меотские дротики // Золото, конь и человек : сб. ст. к 60-летию Александра Владимировича Симоненко. Киев : Скиф. С. 411-416.

Лимберис Н. Ю., Марченко И. И., 2013. Всадническое погребение с умбоном из Среднего Прикубанья // Stratum plus. № 4. C. 105-115.

Лимберис Н. Ю., Марченко И. И., 2019а. Погребения с мечами с кольцевым навершием из могильника меотского городища Спорное // Stratum plus. № 4. С. 189-209.

Лимберис Н. Ю., Марченко И. И., 2019б. Меотские погребения со стеклянными скифосами зубовского типа // Нижневолжский археологический вестник. Т. 18, № 2. С. 235-244. DOI: https://doi.org/10.15688/ nav.jvolsu.2019.2.15

Лимберис Н. Ю., Марченко И. И., 2020. Хронология браслетов с коническими шишечками на концах из меотских памятников Прикубанья // Археология и древняя история Украины. Киев. (В печати).

Лунев М. Ю., 2005. Мечи с кольцевидным навершием в погребениях І в. до н.э. - II в. н.э. Северо-Западного Кавказа // Четвертая Кубанская археологическая конференция : тез. и докл. Краснодар : КубГУ. С. 167-171.

Марченко И. И., 1996. Сираки Кубани (По материалам курганных погребений Нижней Кубани). Краснодар : КубГУ. $336 \mathrm{c.}$

Миллер А. А., 1926. Краткий отчет о работах Северо-Кавказской экспедиции Государственной Академии истории материальной культуры в 1924 и 1925 гг. // Сообщения Государственной академии истории материальной культуры. Вып. 1. Ленинград : Государственная академия истории материальной культуры. С. 82-99.

Монахов С. Ю., 2014. Косские и псевдокосские амфоры и клейма // Stratum plus. № 5. С. 195-222.

Пуздровский А. Е., 2007. Крымская Скифия ІІ в. до н.э. - ІІІ в. н.э. Погребальные памятники. Симферополь : Бизнес-Информ. 480 c.

Розанова Л. С., Терехова Н. Н., 2008. Две производственные традиции в изготовлении предметов вооружения из Цемдолинского некрополя // Аспургиане на юго-востоке азиатского Боспора. По материалам Цемдолинского могильника. М. : ИА РАН. С. 267-271.

Сергацков И. В., 2007. Мечи и кинжалы в среднесарматских памятниках Нижнего Поволжья // Вооружение сарматов: региональная типология и хронология : доклады к VI Междунар. конф. «Проблемы сарматской археологии и истории». Челябинск : ЮУрГУ. С. 58-64.

Симоненко А. В., 2004. Хронология и периодизация сарматских памятников Северного Причерноморья // Сарматские культуры Евразии: проблемы региональной хронологии : доклады к 5-й Междунар. конф. «Проблемы сарматской археологии и истории». Краснодар : КубГУ. С. 134-173.

Симоненко А. В., 2010. Сарматские всадники Северного Причерноморья. СПб. : Факультет филологии и искусств СПбГУ, Нестор-История. 328 с.

Скрипкин А. С., 1990. Азиатская Сарматия. Проблемы хронологии и ее исторический аспект. Саратов : Изд-во СГУ. $299 \mathrm{c}$

Скрипкин А. С., 2010. Сарматы и Восток. Волгоград : Изд-во ВолГУ. 370 с.

Труфанов А. А. 2004. Пряжки ранних провинциально-римских форм в Северном Причерноморье // Российская археология. № 3. С. 160-170.

Хазанов А. М., 1971. Очерки военного дела сарматов. М. : Наука. 169 с.

Ettlinger E., 1973. Die römischen Fibeln in der Schweiz. Bern : Francke. 198 S.

Goethert-Polaschek K., 1977. Katalog der Römischen Gläser des Rheinischen Landsmuseums Trier // Trier Grabungen und Forschungen. Bd. IX. Mainz : von Zabern. 352 S.

Isings C., 1957. Roman Glass from Dated Finds. Djakarta : Groningen. 183 p.

Marčenko I. I., Limberis N. Ju., 2008. Römische importe in sarmatischen und maiotischen Denkmälern des Kubangebietes // Archäologie in Eurasien Bd. 25. S. 265-400. 222 Taf.

Riha E., 1994. Die römischen Fibeln aus Augst und Kaiseraugst. Die Neufunde seit 1975 // Forschungen in Augst. Bd.18. 206 S., 79 Taf.

Schleiermacher M., 1993. Die römischen Fibeln von Kempten-Cambodunum // Cambodunumforschungen. Bd. V. Lassleben : Kallmünz/Opf. 114 S. 


\section{REFERENCES}

Alekseeva E.M., 1975. Antichnye busy Severnogo Prichernomor'ya [Antique Beads of the Northern Pontic Region]. Svod Arkheologicheskih istochnikov. ГI-12. Moscow, Nauka Publ. 94 p.

Alekseeva E.M., 1982. Antichnye busy Severnogo Prichernomor'ya [Antique beads of the Northern Pontic Region]. Svod Arkheologicheskih istochnikov. ГI-12. Moscow, Nauka Publ. 104 p.

Ambroz A. K., 1966. Fibuly yuga Evropeyskoy chasti SSSR II v. do n. e. - IV v. n. e. [Fibulae of the South European Part of USSR $2^{\text {nd }}$ Century BC $-4^{\text {th }}$ Century AD)]. Svod Arkheologicheskih istochnikov. Д1-30. Moscow, Nauka Publ. 111 p., 28 tabl.

Anfimov I.N., 1984. Meotskiy mogil'nik I-II vv. n.e. bliz stanitsy Elizavetinskoy [Maeotian Cemetery of the First Centuries AD near the Village of Elizavetinskaya]. Voprosy arheologii Adygei [Issues of Archaeology of Adygea]. Maykop, Adygean Research Institute of Economics, Language, Literature and History, pp. 83-114.

Anfimov N.V., 1945. Otchet ob arkheologicheskikh issledovaniyakh, provedennykh v Tbilisskom i Ladozhskom rayonakh Krasnodarskogo kraya v 1944 g. [The Report on the Archaeological Research, Working in Tbilisskaya and Ladozhskaya Regions of the Krasnodar Territory in 1944]. Arkhiv IA RAN, Ф-1. P-1. № 5, 39 p., 17 ill.

Anfimov N.V., 1947. Zemlyanye sklepy sarmatskogo vremeni v gruntovykh mogil'nikakh Prikuban'ya [Earth Crypts of the Sarmatian Time in the Burial Grounds of the Kuban Region]. Kratkie soobshcheniya instituta istorii $i$ material'noy kul 'tury [Brief Reports of the Institute of the History of Material Culture], iss. 16, pp. 148-157.

Anfimov N.V., 1951. Meoto-sarmatskiy mogil'nik u stanitcy Ust'-Labinskoy [Maeotian-Sarmatian Burial Ground near the Village of Ust-Labinsk]. Materialy $i$ issledovaniya po arheologii Severnogo Kavkaza [Materials and Research on Archaeology of North Caucasus]. Materialy i issledovaniya po arkheologii SSSR, vol. 23, pp. 155-207.

Anfimov N.V., 1952. Novye materialy po meoto-sarmatskoy kul'ture Prikuban'ya [New Materials on the MaeotianSarmatian Culture of the Kuban Region]. Kratkie soobshcheniya instituta istorii i material'noy kul'tury [Brief Reports of the Institute of the History of Material Culture], iss. 46, pp. 72-85.

Anfimov N.V., 1967. Otchet ob arkheologicheskikh issledovaniyakh, provedennykh v Krasnodarskom kraye v 1966 g. [The Report on the Archaeological Research, working in the Krasnodar Territory in 1966]. Arkhiv IA $R A N$, P-1, № 3806 .

Anfimov N.V., 1968, Otchet ob arkheologicheskikh rabotakh, svyazannykh s okhrannymi meropriyatiyami, provedennykh v $1967 \mathrm{~g}$. [The Report on the Archaeological Works, related to conservation activities, carried out in 1967]. Arkhiv IA RAN, P-1, № 3807.

Anfimov N.V., 1973. Otchet o raskopkakh Pashkovskogo 5-go mogil'nika v 1972 g. [The Report on the Excavations of the $5^{\text {th }}$ Pashkovskaya Burial Ground in 1972]. Arkhiv IA RAN, P-1, № 6505.

Berlizov N.E., Anfimov I.N., 2005. Mogil'niki Srednego Prikuban'ya epohi pozdnego ellinizma i rimskogo vremeni (po materialam rukopisnogo arkhiva N.V. Anfimova) [The Cemeteries of the Middle Kuban Region of the Late Hellenistic and Roman Times (based on the materials of N.V. Anfimovs manuscript archive)]. Materialy $i$ issledovaniya po arheologii Severnogo Kavkaza [Materials and Research on Archaeology of the North Caucasus], iss. 5. Armavir, Armavir State Pedagogical University, pp. 113-125.

Bochkovoy V.V., Limberis N.Yu., Marchenko I.I/, 2005. Pogrebeniya s amforami iz mogil'nika gorodishcha Spornoye [The Burials with Amphorae from the Cemetery of the Spornoye Settlement]. Materialy i issledovaniya po arheologii Kubani [Materials and Research on Archaeology of the Kuban Region], iss. 5. Krasnodar, KubSU, pp. 172-218.

Vysotskaya T.N., 1994. Ust'-Al'minskoe gorodishche i nekropol'. Materialy po arkheologii Kryma [Ust-Alma Fortified Settlement and Necropolis. Materials on the Archaeology of Crimea]. Kiev, Eurobusiness Academy. 208 p.

Zasetckaya I.P., Marchenko I.I., 1995. Klassifikatciya steklyannykh kanfarov pozdneellinisticheskogo i rannerimskogo vremeni [Classification of Glass Kantharoi of the Late Hellenistic and Early Roman Times]. Arheologicheskiy sbornik gosudarstvennogo Ermitazha [Archaeological Papers of the State Hermitage Museum], iss. 32, pp. 90-104.

Kozhukhov S.P., 1994. Vooruzheniye i konskoye snaryazheniye u plemen Zakuban'ya v meoto-sarmatskoye vremya (III v. do n.e. - III v. n.e.): avtoref. dis. ... kand. ist. nauk [Armament and Horse Equipment among the Trans- 
N.Yu. Limberis, I.I. Marchenko. Chronology of the Swords with Ring Pommel from the Maeotian Sites

Kuban Tribes in the Maeotian-Sarmatian Time (III century BC - III century AD). Cand. hist. sci. abs. diss]. Moscow, IA RAS. 22 p.

Korpusova V.N., 1983. Nekropol'Zolotoe (K etnokul 'turnoy istorii evropeyskogo Bospora) [Necropolis of Golden (On the Ethnocultural History of the European Bosporus)]. Kiev, Naukova Dumka Publ. 184 p.

Kosyanenko V.M., 1987. Bronzovye fibuly iz nekropolya Kobyakova gorodishcha [Bronze Fibulae from the Necropolis of the Kobyakov Fortified Settlement]. Sovetskaya Arkheologiya [Soviet Archaeology], no. 2, pp. 45-62.

Kosyanenko V.M., 2008. Nekropol' Kobyakova gorodishcha (po materialam raskopok 1956-1962 gg.) [Necropolis of the Kobyakovo Settlement (Based on Excavations from 1956-1962)]. Donskie drevnosti [Don Antiquities], vol. 9. Azov, Azov Historical, Archaeological and Paleontological Museum-Reserve. 544 p.

Kropotov V.V., 2010. Fibuly sarmatskoy epokhi [Fibulae of the Sarmatian Epoch]. Kiev, IA NASU, ADEF-Ukraina Publ. 384 p.

Kunina N., 1997. Antichnoe steklo v sobranii Ermitazha [Antic Glass in Herminage Collection]. St. Peterburg, State Hermitage, ARS. 358 p.

Limberis N.Yu., Marchenko I.I., 1989. Khronologiya mechey iz sarmatskikh pamyatnikov Prikuban'ya [Chronology of Swords from the Sarmatian Monuments of the Kuban Region]. Pervaya kubanskaya arheologicheskaya konferenciya [First Kuban Archaeological Conference]. Krasnodar, KubSU, pp. 80-82.

Limberis N.Yu., Marchenko I.I., 2003. Steklyannye sosudy pozdneellinisticheskogo i rimkogo vremeni iz Prikuban'ya [Late Hellenistic and Roman Glass Vessels from Kuban Region]. Materialy i issledovaniya po arheologii Kubani [Materials and Research on Archaeology of the Kuban Region], iss. 3. Krasnodar, KubSU, pp. 106-183.

Limberis N.Yu., Marchenko I.I., 2005. Khronologiya keramicheskikh kompleksov s antichnymi importami iz raskopok meotskikh mogil'nikov pravoberezh'ya Kubani [Chronology of the Ceramics Complexes with Antique Imports from the Excavations of the Maeotian Burial Grounds on the Right Bank of the Kuban River]. Materialy $i$ issledovaniya po arheologii Kubani [Materials and Research on Archaeology of the Kuban Region], iss. 5. Krasnodar, KubSU, pp. 219-324.

Limberis N.Yu., Marchenko I.I., 2006. Tipologiya i khronologiya zheleznykh nakonechnikov kopiy iz pamyatnikov pravoberezh'ya Kubani [Typology and Chronology of the Iron Spearheads from the Sites of the Kuban River Right Bank]. Materialy i issledovaniya po arheologii Kubani [Materials and Research on Archaeology of the Kuban Region], iss. 6. Krasnodar, KubSU, pp. 152-181.

Limberis N.Yu., Marchenko I.I., 2012. Meotskie drotiki [Maeotian darts]. Zoloto, kon'i chelovek: sbornik statey $k$ 60-letiyu Aleksandra Vladimirovicha Simonenko [Gold, horse and man. Papers of articles to the $60^{\text {th }}$ anniversery of Alexandr Vladimirovich Simonenko]. Kiev, Skif Publ., pp. 411-416.

Limberis N.Yu., Marchenko I.I., 2013. Vsadnicheskoye pogrebeniye s umbonom iz Srednego Prikuban'ya [The Equestrian Burial with Shield-Boss from Middle Kuban]. Stratum plus, no. 4, pp. 105-115.

Limberis N.Yu., Marchenko I.I., 2019a. Pogrebeniya s mechami s kol'cevym navershiem iz mogil'nika meotskogo gorodishcha Spornoye [Graves with Ring-Topped Swords from the Burial Ground of the Maeotian Fortified Settlement Spornoye]. Stratum plus, no. 4, pp. 189-209.

Limberis N.Yu., Marchenko I.I., 2019b. Meotskie pogrebeniya so steklyannymi skifosami zubovskogo tipa [Maeotian Burials with Glass Skyphos of Zubovsky Type]. Nizhnevolzhskiy Arheologicheskiy Vestnik [The Lower Volga Archaeological Bulletin], vol. 18, no. 2, pp. 235-244. DOI: https://doi.org/10.15688/ nav.jvolsu.2019.2.15

Limberis N.Yu., Marchenko I.I., 2020. Khronologiya brasletov s konicheskimi shishechkami na kontcakh iz meotskikh pamyatnikov Prikuban'ya [Chronology of the arm-rings with conical cones at the ends from the Maeotian monuments of the Kuban Region]. Arhaeologiya i drevnyaya istoriya Ukrainy [Archaeology and Ancient History of Ukraine]. Kiev. (in print).

Lunyov M.Yu., 2005. Mechi s kol'cevidnym navershiem v pogrebeniyakh I v. do n.e. - II v. n.e. Severo-Zapadnogo Kavkaza [Swords with a Ring Top in the North-West Caucasus Burials of the $1^{\text {st }}$ century BC - II century AD]. Chetvertaya Kubanskaya arheologicheskaya konferenciya. Tezisy i doklady [Fourth Kuban Archaeological Conference. Abstracts and Reports]. Krasnodar, KubSU, pp. 167-171.

Marchenko I.I., 1996. Siraki Kubani (Po materialam kurgannykh pogrebeniy Nizhney Kubani) [Siraces of the Kuban (Based on the materials from burial mounds of the Lower Kuban)]. Krasnodar, KubSU. 336 p. 
Miller A.A., 1926. Kratkiy otchet o rabotakh Severo-Kavkazskoy ekspedicii Gosudarstvennoy Akademii istorii material'noy kul'tury v 1924 i 1925 gg. [The Short Report on the Work of the North Caucasian Expedition of the State Academy of the History of Material Culture in 1924 and 1925]. Soobshcheniya GAIMK [Reports of the State Academy of the History of Material Culture], iss. 1, pp. 82-99.

Monakhov S.Yu., 2014. Kosskiye i psevdokosskiye amfory i kleyma [Koan and Pseudo-Koan Amphorae and Stamps]. Stratum plus, no. 5, pp. 195-222.

Puzdrovskiy A.E., 2007. Krymskaya Skifiya II v. do n.e. - III v. n.e. Pogrebal'nye pamyatniki [Crimean Scythia II Century BC - III Century AD. Funeral Monuments]. Simferopol, Business Inform Publ. 480 p.

Rozanova L.S., Terekhova N.N., 2008. Dve proizvodstvennye traditcii v izgotovlenii predmetov vooruzheniya iz Tcemdolinskogo nekropolya [Two Manufacturing Traditions in the Production of Weapons from the Tsemdolina Necropolis]. Aspurgiane na yugo-vostoke aziatskogo Bospora. Po materialam Tcemdolinskogo mogil'nika [Aspurghians in the South-Est of the Asian Bosporus. Based on Materials from the Tsemdolina Burial Ground]. Moscow, IA RAS, pp. 267-271.

Sergatckov I.V., 2007. Mechi i kinzhaly v srednesarmatskih pamyatnikakh Nizhnego Povolzh'ya [Swords and Daggers in the Middle Sarmatian Monuments of the Lower Volga]. Vooruzhenie sarmatov: regional'naya tipologiya $i$ hronologiya. Doklady k VI mezhdunarodnoy konferencii "Problemy sarmatskoy arheologii $i$ istorii» [Armament of the Sarmatians: regional typology and chronology. Reports to the VI international conference "Problems of Sarmatian archeology and history"]. Chelyabinsk, SUSU, pp. 58-64.

Simonenko A.V., 2004. Khronologiya i periodizatciya sarmatskikh pamyatnikov Severnogo Prichernomor'ya [Chronology and Periodization of the North Pontic Region Sarmatian Monuments ]. Sarmatskie kul'tury Evrazii: problemy regional'noy khronologii. Doklady $k$ 5-y mezhdunarodnoy konferencii «Problemy sarmatskoy arheologii i istorii» [Sarmatian Cultures of Eurasia: Problems of Regional Chronology. Reports to the $\mathrm{V}$ international conference "Problems of Sarmatian archeology and history"]. Krasnodar, KubSU, pp. 134-173.

Simonenko A.V., 2010. Sarmatskie vsadniki Severnogo Prichernomor'ya [Sarmatian Riders of North Pontic Region]. St. Petersburg, Faculty of Phililogy and Arts of the St. Petersburg State University, Nestor-Historia Publ. $328 \mathrm{p}$.

Skripkin A.S., 1990. Aziatskaya Sarmatiya. Problemy khronologii i ee istoricheskiy aspect [Sarmatia Asiatica. Problems of Chronology and its Historical Aspect]. Saratov, SSU. 299 p.

Skripkin A.S., 2010. Sarmaty i Vostok [Sarmatians and East]. Volgograd, VolSU. 370 p.

Trufanov A.A., 2004. Pryazhki rannikh provincial'no-rimskikh form v Severnom Prichernomor'e [Buckles of the Early Provincial Roman Forms in the North Pontic Region]. Rossiyskaya Arkheologiya [Russian Archaeology], no. 3, pp. 160-170.

Khazanov A.M., 1971. Ocherki voennogo dela sarmatov [Essays on Military Affairs of the Sarmatians]. Moscow, Nauka Publ. 169 p.

Ettlinger E., 1973. Die römischen Fibeln in der Schweiz. Bern: Francke. 198 S.

Goethert-Polaschek K., 1977. Katalog der Römischen Gläser des Rheinischen Landsmuseums Trier. Trier Grabungen und Forschungen, Bd. IX. Mainz am Rhein, von Zabern. $352 \mathrm{~S}$.

Isings C., 1957. Roman Glass from Dated Finds. Groningen, Diakarta. 183 p.

Marčenko I.I., Limberis N.Ju., 2008. Römische importe in sarmatischen und maiotischen Denkmälern des Kubangebietes. Archäologie in Eurasien, Bd. 25. S. 265-400, 222 Taf.

Riha E., 1994. Die römischen Fibeln aus Augst und Kaiseraugst. Die Neufunde seit 1975. Forschungen in Augst. Bd.18. 206 s., 79 taf.

Schleiermacher M., 1993. Die römischen Fibeln von Kempten-Cambodunum. Cambodunumforschungen. Bd. V. Lassleben, Kallmünz/Opf. 114 S. 
N.Yu. Limberis, I.I. Marchenko. Chronology of the Swords with Ring Pommel from the Maeotian Sites

\section{Information About the Authors}

Natalya Yu. Limberis, Senior Researcher, Scientific Research Institute of Archaeology, Kuban State University, Stavropolskaya St., 149, 350040 Krasnodar, Russian Federation, meot@mail.ru, https://orcid.org/0000-0003-0395-315X

Ivan I. Marchenko, Candidate of Sciences (History), Professor, Department of World History and International Relations, Kuban State University, Stavropolskaya St., 149, 350040 Krasnodar, Russian Federation,meot@mail.ru,https://orcid.org/0000-0001-7319-5214

\section{Информация об авторах}

Наталья Юрьевна Лимберис, старший научный сотрудник НИИ археологии, Кубанский государственный университет, ул. Ставропольская, 149, 350040 г. Краснодар, Российская Федерация, meot@mail.ru, https://orcid.org/0000-0003-0395-315X

Иван Иванович Марченко, кандидат исторических наук, профессор кафедры всеобщей истории и международных отношений, Кубанский государственный университет, ул. Ставропольская, 149, 350040 г. Краснодар, Российская Федерация, meot@mail.ru, https://orcid.org/0000-0001-7319-5214 